\title{
Low back pain among bodybuilding professors of the West zone of the city of Rio de Janeiro
}

\author{
Lombalgia em professores de musculação da zona oeste da cidade do Rio de Janeiro \\ Jurandir Baptista da Silva', Rodrigo Gomes de Souza Vale1, Flavio da Silva², Adeilson Chagas², Giovanne Moraes², Vicente P. Lima²
}

DOI 10.5935/1806-0013.20160005

\section{ABSTRACT}

BACKGROUND AND OBJECTIVES: Low back pain is one of the most common musculoskeletal symptoms in industrialized societies, according to the World Health Organization. This study aimed at investigating the prevalence of low back pain among bodybuilding professors of fitness centers of the city of Rio de Janeiro and at observing correlations between age, working time, working hours and low back pain intensity.

METHODS: The adapted questionnaire of the Quebec Pain Disability Scale was applied to 50 physical education professors of both genders (age $=31.86 \pm 6.86$ years) working with bodybuilding in fitness centers, with minimum weekly working hours of $12 \mathrm{~h}$, and at least three years acting in the area. This was a survey-type descriptive cross-sectional study.

RESULTS: From 50 interviewed professors, 62\% have stated not feeling any type of lumbar discomfort, while just 38\% have stated feeling some type of pain. From these, $20 \%$ have stated feeling daily pain, $6 \%$ weekly and $12 \%$ have reported monthly pain. About pain intensity in its worst moment, $14 \%$ have stated it is mild, $20 \%$ moderate and just $6 \%$ have reported severe pain. There has been positive and significant correlation $(\mathrm{p}<0.05)$ between age and working time and between working time and low back pain intensity.

CONCLUSION: Low back pain prevalence was not high among interviewed professionals. Results show that older individuals working for a longer time are those with more severe low back pain.

Keywords: Age, Low back pain, Prevalence, Professor, Work.

1. Universidade do Estado do Rio de Janeiro, Rio de Janeiro, RJ, Brasil

2. Universidade Castelo Branco, Grupo de Pesquisa em Biodinâmica do Exercício, Saúde e Performance, Rio de Janeiro, RJ, Brasil.

Submitted in October 21, 2015.

Accepted for publication in January 18, 2016.

Conflict of interests: none - Sponsoring sources: none.

Correspondence to:

Jurandir Baptista da Silva

Estrada Caetano Monteiro, 391 A - Bloco 1/201 - Badu

24230-570 Niterói, RJ, Brasil.

E-mail: profjurandirsilva@hotmail.com

(C) Sociedade Brasileira para o Estudo da Dor

\section{RESUMO}

JUSTIFICATIVA E OBJETIVOS: A dor lombar é um dos sintomas musculoesqueléticos mais comuns nas sociedades industrializadas, de acordo a Organização Mundial de Saúde. O objetivo do estudo foi investigar a prevalência de dor lombar em professores que atuam na atividade de musculaçáo em academias de ginástica no município do Rio de Janeiro e verificar as correlaçóes entre idade, tempo de trabalho, horas de trabalho e intensidade da dor lombar.

MÉTODOS: Foi aplicado o Questionário adaptado do Quebec Pain Disability Scale em 50 professores de Educação Física de ambos os gêneros (idade $=31,86 \pm 6,86$ anos) que trabalham na musculação em academias de ginástica, com jornada semanal mínima de $12 \mathrm{~h}$ de trabalho, e ao menos três anos de atuação prática na área. $\mathrm{O}$ trabalho foi caracterizado como um estudo descritivo, de corte transversal do tipo Survey.

RESULTADOS: Dos 50 professores entrevistados, $62 \%$ alegaram não sentir qualquer tipo de desconforto na regiâo lombar, enquanto apenas $38 \%$ afirmaram sentir algum tipo de dor. Desses, $20 \%$ alegaram que a manifestação da dor é diária, $6 \%$ semanal e $12 \%$ relataram que as dores são mensais. Sobre a intensidade da dor em seu pior momento, $14 \%$ afirmaram ser suave, $20 \%$ moderada e apenas $6 \%$ relataram dores intensas. Observou-se correlação positiva e significativa $(\mathrm{p}<0,05)$ entre a idade e tempo de trabalho e entre tempo de trabalho e intensidade da dor lombar. CONCLUSÁO: A prevalência de dor lombar não foi alta nos profissionais pesquisados da amostra. Os resultados apontam que os indivíduos com mais idade e que possuem mais tempo de trabalho são os que apresentam dor lombar em níveis mais elevados. Descritores: Dor lombar, Idade, Prevalência, Professor, Trabalho.

\section{INTRODUCTION}

Low back pain is one of the most common musculoskeletal symptoms in industrialized societies ${ }^{1}$. According to the World Health Organization (WHO), approximately $80 \%$ of adults shall suffer at least one acute back pain crisis during life, being that $90 \%$ of them shall have more than one low back pain (LBP) episode ${ }^{2}$ So, LBP should be seen as a public health problem because such morbidity primarily affects economically active populations and may be highly disabling, in addition to major impact on quality of life (QL), being one of the most common reasons for total or partial disability ${ }^{3}$. 
LBP may have as causes some congenital, degenerative, inflammatory, infectious, tumor or mechanical-postural conditions. Mechanical-postural low back pain, also called unspecific low back pain, represents a large part of spinal pains referred by people .

Among causes of occupational low back pain, individual factors such as gender, age, height, obesity, muscle strength related to professional demands, lumbar region muscles resistance, smoking and organizational factors such as vigorous or heavy movements, spinal flexion and torsion, vibration of the whole body and physically tiresome activities have been stressed. This condition is consequence of imbalance between functional load and functional capacity, where effort required by working and daily life activities is greater than the execution potential for such activities ${ }^{5}$.

Physical Education professionals have mechanical-postural low back pain related to their profession and muscle contractures caused by this condition interfere with the performance of daily activities, causing from movement limitation and medical leave to temporary disability depending on disease intensity ${ }^{6}$.

Studies have observed the incidence of LBP in several professions ${ }^{7,8}$; however, information in the literature about this condition among Physical Education professionals is still not well explained. In this sense, it is important to identify LBP and its probable causes in these professors to improve their daily lives both at work and leisure time. In addition, this type of approach has the best cost-benefit ratio for the company and its employees, because the problem is detected early, helping the prevention of musculoskeletal disorders?. So, as a function of possible profession-related spinal disorders and the implications of this disease on lives of physical education professionals, this study aimed at investigating the prevalence of LBP among bodybuilding professors in the city of Rio de Janeiro, and at checking correlations between age, working time, working hours and LBP intensity.

\section{METHODS}

This is a descriptive, cross-sectional Survey-type study. Study was made up of 50 Physical Education professors of both genders, with $31.86 \pm 6.86$ years of age, being $32(64 \%)$ males and $18(36 \%)$ females. Subjects acted in bodybuilding activities in gyms, with minimal weekly journey of $12 \mathrm{~h}$, and at least three years of practical action, including their training period. Excluded from the sample were individuals who at data collection time had injury or disease which could develop low back pain.

Visits were carried out in 23 gyms of the city of Rio de Janeiro, in the districts of Realengo, Campo Grande, Mesquita and Magalhães Bastos. Professors present at the time and matching inclusion criteria were interviewed and have signed the Free and Informed Consent Term (FICT) to participate in studies involving human beings, according to guidelines of Resolution 466/2012, of the National Health Council and the Declaration of Helsinki ${ }^{10}$.
A self-applicable epidemiological questionnaire adapted from the Quebec Pain Disability Scale questionnaire was used to check the prevalence of LBP, giving emphasis to questions about LBP, age, frequency of physical activities, working hours and psychosocial factors. This tool has been applied to health area professionals and is aimed at getting some data to allow the development of a health education program ${ }^{11}$.

\section{Statistical analysis}

Data were processed by the statistical program SPSS 20 for Windows and are presented descriptively with mean, standard deviation and frequency of questionnaire answers. Spearman correlation test was used to analyze possible associations between studied variables, considering significant $\mathrm{p}<0.05$.

This study is part of the low back pain and physical activity research line of the BIODESP research (Biodinâmica do Exercício, Saúde e Performance) submitted to the Research Ethics Committee, Universidade Federal do Estado do Rio de Janeiro, and approved by opinion 724.611 .

\section{RESULTS}

Professional activity characteristics of the sample are shown in table 1 . Most sample worked more than $8 \mathrm{~h}$ per day and acted on the profession for 4 to 7 years. Most professors have reported having pauses when they remain sitting during the day.

Table 1. Description of activity

\begin{tabular}{lcc}
\hline Ativities & $\mathrm{n}$ & $\%$ \\
\hline For how long do you work as professor? (years) & & \\
Less than 2 & 0 & 0 \\
Between 2 and 4 & 18 & 36 \\
Between 5 and 7 & 20 & 40 \\
More than 7 & 12 & 24 \\
How many hours do you work per day? & & \\
$>8$ & 9 & 18 \\
8 - 12 & 39 & 78 \\
$<12$ & 2 & 4 \\
Are there pauses in your work? & & \\
Yes & 48 & 96 \\
No & 2 & 4 \\
How many? & & \\
1 & 13 & 26 \\
2 & 30 & 60 \\
3 & 1 & 2 \\
More than 3 & 4 & 8 \\
In which position do you remain during these pauses? & \\
Standing still & 43 & 86 \\
Walking & 2 & 4 \\
\hline & 3 & 6 \\
\hline
\end{tabular}


Table 2 shows sample psychosocial relationships. Most participants were happy with their work, have considered their mood as normal and have stated having a good relationship at work. Most part of respondents have also leisure activities, have many friends and have physical activities included in their routine. However, they feel physically and mentally tired at the end of the working day.

Table 2. Psychosocial questions

\begin{tabular}{lcc}
\hline & $\mathrm{n}$ & $\%$ \\
\hline Are you happy with your work? & 43 & 86 \\
Yes & 7 & 14 \\
No & 49 & 98 \\
Do you have a good working environment relationship? & \\
Yes & 1 & 2 \\
No & 0 & 0 \\
Do you have many friends outside the working environment? & \\
None & 10 & 20 \\
Few & 21 & 42 \\
Enough & 19 & 38 \\
Many &
\end{tabular}

How many times a week do you practice leisure activities?

$\begin{array}{lcc}\text { None } & 9 & 18 \\ \text { Once } & 9 & 18 \\ \text { Twice } & 20 & 40 \\ 3 \text { times or more } & 12 & 24\end{array}$

Which of the options below better characterize your mood?

Normal

Anxious

Frequent sadness

Easily irritated

Do you regularly practice physical activity?

Yes

No

How many times a week?

Once

Twice

3 times or more

$40 \quad 80$

$7 \quad 14$

00

36

Physically, how do you feel after work?

Well

Tired

Somewhat tired

Very tired

Mentally, how do you feel after work?

Well

Tired

Somewhat tired

$47 \quad 94$

36

Very tired

$18 \quad 36$

$26 \quad 52$

1122

$4 \quad 8$

$8 \quad 16$

$27 \quad 54$

$10 \quad 20$

$5 \quad 10$
Table 3 shows LBP-related results. It was observed that less than half the sample has reported low back pain, and when present it was predominantly daily. Notwithstanding the low prevalence, pain was reported by part of the sample as being present in the last few days and was enough to move professors away from work.

Table 3. Low back pain analysis

\begin{tabular}{|c|c|c|}
\hline & $\mathrm{n}$ & $\%$ \\
\hline \multicolumn{3}{|c|}{ Lumbar region pain or discomfort } \\
\hline Yes & 19 & 38 \\
\hline No & 31 & 62 \\
\hline \multicolumn{3}{|c|}{ Accident/disease involving lumbar region } \\
\hline Yes & 3 & 6 \\
\hline No & 47 & 94 \\
\hline \multicolumn{3}{|c|}{ Low back pain frequency } \\
\hline I have no pain & 31 & 62 \\
\hline Daily & 10 & 20 \\
\hline Weekly & 3 & 6 \\
\hline Monthly & 6 & 12 \\
\hline \multicolumn{3}{|c|}{ Pain intensity at its worst moment } \\
\hline None & 30 & 60 \\
\hline Mild & 7 & 14 \\
\hline Moderate & 10 & 20 \\
\hline Severe & 3 & 6 \\
\hline \multicolumn{3}{|c|}{ Pain before working as professor } \\
\hline Yes & 4 & 8 \\
\hline No & 46 & 92 \\
\hline \multicolumn{3}{|c|}{ Change of activity/function due to low back pain } \\
\hline Yes & 6 & 12 \\
\hline No & 44 & 88 \\
\hline \multicolumn{3}{|c|}{ Decreased activities in the last 12 months } \\
\hline Yes & 12 & 24 \\
\hline No & 38 & 76 \\
\hline
\end{tabular}

Impediment of activities in the last 12 months (days)

$$
0
$$

1 to 7

8 to 15

More than 15 days

$35 \quad 70$

Presence of low back pain in the last 7 days

Yes

No

$12 \quad 24$

36

$0 \quad 0$

Any current treatment

Yes

No

$12 \quad 24$

$38 \quad 76$

Which?

Physiotherapy $\quad 2 \quad 50$

Drug 00

Both

250 
Table 4 shows the correlation between variables age, working time (WT), working hours (WH) and low back pain intensity (LBPI) in subjects with LBP. There has been positive and significant correlation $(\mathrm{p}<0.05)$ of WT with age and LBP. This shows that older individuals and working for a longer time are those with higher levels of LBP.

Table 4. Correlation between variables age, working time, working hours and low back pain intensity in subjects with low back pain

\begin{tabular}{lcccc}
\hline & & Age & WT & WH \\
\hline WT & $r$ & $0.877^{\star}$ & & \\
& $p$ value & 0.000 & & \\
WH & $r$ & 0.198 & 0.205 & \\
& $p$ value & 0.416 & 0.401 & \\
LBPI & $r$ & 0.389 & $0.479^{\star}$ & 0.385 \\
& $p$ value & 0.100 & 0.038 & 0.104 \\
\hline
\end{tabular}

${ }^{*} p<0.05$.

$\mathrm{WT}=$ working time; $\mathrm{WH}=$ working hours; $\mathrm{LBPI}=$ low back pain intensity.

\section{DISCUSSION}

Based on the questionnaire it was observed that the prevalence of low back pain among bodybuilding professors of our sample was low, considering that pain was perceived by $38 \%$ of individuals.

Almeida et al. ${ }^{1}$ have investigated the association of different factors, such as gender, age and lifestyle with chronic LBP in 2297 people in Salvador, Bahia. Authors have observed that low back pain is correlated to age and working time. This confirms our study, which indicates that successive working journeys may negatively influence QL.

Pinto et al. ${ }^{12}$ have observed LBP in 260 males with mean age of $27.6 \pm 6.8$ years, who practiced bodybuilding in gyms of Meier, district of Rio de Janeiro. Authors have found prevalence of $47.3 \%(n=123)$. These results are similar to our study, which has observed that $38 \%$ of respondents have reported some type of LBP. However, in spite of bodybuilding professors being used to this type of exercise to maintain fitness or as leisure, studies are not totally correlated because our study has observed prevalence just in professors, and leisure exercises may influence pain results. Another important data show that in both studies, part of the sample has not lost a single working day due to this pain.

A different study ${ }^{13}$ with training against resistance practitioners has observed that $57.1 \%$ of sample have reported LBP. Such results are different from our study, which has observed prevalence of $38 \%$. These results may be explained by the fact that our study has observed LBP in bodybuilding professors, in whom the knowledge of ergonomics and biomechanics may influence their posture during work, minimizing spinal overload and consequently pain.

Siqueira, Cahú and Vieira ${ }^{14}$ have used a similar methodology to evaluate LBP in 56 physiotherapists, also health professionals, and have found that $78.58 \%$ of these profession- als had low back pain. These results are different from our study which has observed a lower prevalence of this type of pain. This might be justified by different ways of acting between both professions, since physiotherapy has a characteristic of intense body segments manipulation, which seldom is the case in the routine of bodybuilding professors.

Notwithstanding the low prevalence of pain (38\%) observed at questionnaire application moment, it is important to stress that inadequately treated mechanical-postural low back pain may trigger a cascade of events. So, even with spontaneous pain relief, recurrence indices are huge and there might be pain potentiation, the acute moment of which may become chronic.

Our study has not evaluated other pain sites such as cervical spine, shoulders and knees, which could be affecting participants due to posture and working standing. This might be considered a limitation of the study due to different practices developed in bodybuilding rooms.

\section{CONCLUSION}

Our study has explored the prevalence of LBP in physical education professors working with bodybuilding. Our results have shown low prevalence of low back pain in the sample, notwithstanding the stress imposed by the job, high exercise loads and long working hours, where different daily movements bring different spinal overloads (compression, shearing and bending). Further studies are suggested with a larger number of physical education professionals of different age groups and working times.

\section{REFERENCES}

1. Almeida IC, Sá KN, Silva M, Baptista A, Matos MA, Lessa I. Prevalência de dor lombar crônica na população da cidade de Salvador. Rev Bras Ortop. 2008;43(3):96-102.

2. Matos MA, Lessa I. Organização Mundial de Saúde - OMS; Organização Panamericana de Saúde - OPAS. CIF - Classificação Internacional de Funcionalidade, Incapacidade e Saúde. São Paulo: Universidade de São Paulo, 2003.

3. Kent PM, Keating JL. The epidemiology of low back pain in primary care. Chiropr Osteopat. 2005;13:1.

4. Andrade SC, Araújo AG, Vilar MJ. Escola de Coluna: revisão histórica e sua aplicação na lombalgia crônica. Rev Bras Reumatol. 2005;45(4):224-8.

5. Bayramoglu M, Akman M, Kilinç S, Cetin N, Yavuz N, Ozker R. Isokinect measurement of trunk muscle strength in women with chronic low-back pain. Am J Phys Med Rehabil. 2001;80(9):650-5.

6. Marras WS. Occupational low back disorder causation and control. Ergonomics. 2000;43(7):880-902.

7. Rubio K, Godoy Moreira F. A representaçăo de dor em atletas olímpicos brasileiros. Rev Dor. 2007;8(1):926-5.

8. Fernandes RA, Cardoso JR. Lombalgia ocupacional e a postura sentada: efeitos da cinesioterapia laboral. Rev Dor. 2012;12(4):308-13.

9. Rosecrance JC, Cook TM, Zimmermann CL. Active surveillance for the control of cumulative trauma disorders: a working model in the newspaper industry. J Orthop Sports Phys Ther. 1994;19(5):267-76.

10. World Medical Association Declaration of Helsinki. Ethical principles for medical research involving human subjects. Bull Word Health Organ. 2001;79(4):373-4.

11. Shimabukuro VG, Alexandre NM, Coluci MZ, Rosecrance JC, Gallani MC. Validity and reliability of a job factors questionnaire related to the work tasks of physical therapists. Int J Occup Saf Ergon. 2012;18(1):15-26.

12. Pinto SM, Silva MA, Novaes JS, Batista LA. Prevalência de lombalgia em praticantes de musculaçăo. Fisioter Bras. 2008;9(3):189-93.

13. Santos KD, Silva MA, Pereira JS, Batista LA. Prevalência de lombalgia em praticantes de exercício contra-resistência. Fisioter Bras. 2004:5(1):37-43.

14. Siqueira GR, Cahú FG, Vieira RA. Ocorrência de lombalgia em fisioterapeutas da cidade de Recife, Pernambuco. Rev Bras Fisioter. 2008;12(3):222-7. 